(C) 2016. This manuscript version is made available under the CC-BY-NC-ND 4.0 license http://creativecommons.org/licenses/by-nc-nd/4.0/

Publisher version: doi: 10.1061/(ASCE)HY.1943-7900.0001212

1 Preprint of Capape, S., Martín-Vide, J., and Colombo, F. (2016). "Subaqueous Barchans and

2 Plane Beds from Deposition of Quartz Silt." J. Hydraul. Eng., 10.1061/(ASCE)HY.1943-

$37900.0001212,06016020$

\title{
4 Subaqueous Barchans and Plane Beds from Deposition of Quartz Silt
}

\section{S. Capape ${ }^{1 *}$, J.P. Martín-Vide ${ }^{2}$, and F. Colombo ${ }^{3}$}

$\underline{\text { Abstract }}$

The suspension flow of quartz silt (geometric mean grain size of 4.15 microns), in unfavourable conditions for the deposition, originates the development of different bed morphologies. Particles deposit over a plane, non-erodible surface and develop well-defined barchan ripples, barchanoids and plane beds in flume experiments. Bed-load transport of quartz silt by bedform migration is several orders of magnitude smaller than the suspended transport. The final bed morphology is controlled by the suspended sediment concentration and the running time of the experiment. The average dimensions of the bedforms after one-day experiments are $4.93 \mathrm{~cm}$ wide, $10.33 \mathrm{~cm}$ long and $0.45 \mathrm{~cm}$ high. Cohesive plane beds appear after two and three-days experiments with very high sediment concentration $\left(\geq 22.5 \mathrm{~kg} / \mathrm{m}^{3}\right)$. Viscous effects are deemed relevant for the formation of the beds. DOI: 10.1061/(ASCE)HY.1943-7900.0001212. (C) 2016 American Society of Civil Engineers.

\footnotetext{
${ }^{1}$ Ph.D Student, Technical University of Catalonia-BarcelonaTech, Barcelona, Catalonia.

*Corresponding author c/ Jordi Girona 1, D1-204, 08034 Barcelona, Catalonia, Spain. E-mail: sergi.capape@upc.edu

${ }^{2}$ Professor, Technical University of Catalonia-BarcelonaTech, 08034, Barcelona, Catalonia, Spain

${ }^{3}$ Professor, SIMGEO UB-CSIC, Departament d'Estratigrafia, Paleontologia i Geociències Marines, Universitat de Barcelona, 08028, Barcelona, Catalonia, Spain

Note. This manuscript was submitted on September 7, 2015; approved on May 24, 2016; published online on August 3, 2016. Discussion period open until January 3, 2017; separate discussions must be submitted for individual papers. This technical note is part of the Journal of Hydraulic Engineering, C ASCE, ISSN 0733-9429.
} 
(C) 2016. This manuscript version is made available under the CC-BY-NC-ND 4.0 license http://creativecommons.org/licenses/by-nc-nd/4.0/

Publisher version: doi: 10.1061/(ASCE)HY.1943-7900.0001212

$\underline{\text { Introduction }}$

19 Common knowledge points to conditions for a significant sediment suspension when the shear

20 velocity is much larger than the settling velocity of the particles (Bagnold 1966). The flow

21 properties, the sediment concentration, the particle size distribution and the cohesive attributes

22 affect the deposition of the particles (Baas et al. 2011; Jopling and Forbes 1979). In the experiments

23 reported here, although the shear velocity was considerably larger than the settling velocity of the

24 particles, multiple bed morphologies developed from the deposition of quartz silt (geometric mean

25 grain size of $4.15 \mu \mathrm{m}$ ) over a plane, rigid, non-erodible surface in turbulent conditions. In this

26 article, the authors show evidence for the bed formation, with few examples in the literature (e.g.

27 Jopling and Forbes (1979)).

28 An extensive catalogue of bedforms can emerge on the bed from the interaction between the flow

29 and the bed material (Allen 1968) although a noncohesive sediment with a median smaller than

$30150 \mu \mathrm{m}$ confines the possibilities of bedforms to ripples (Southard and Boguchwal 1990). Ripples

31 may be defined as small bedforms independent of flow depth but dependent of the grain size

32 distribution that scale with the thickness of the viscous sublayer (Jopling and Forbes 1979; Mantz

33 1992). Over time, the ripples grow and evolve towards an equilibrium 3D linguoid shape (Baas

34 1994, 1999; Mantz 1992; Raudkivi 1997). When the ultimate equilibrium bed displays no linguoid

35 geometries in plan, it is interpreted as a lack of equilibrium because either there has been

36 insufficient time to develop the geometry or there is a deficit of supply of noncohesive granular

37 material (Baas et al. 2013). The equilibrium bedform sequence from a stationary flat bed shows

38 barchanoid ripples followed by linguoid ripples with increasing flow discharge (Mantz 1992).

39 Linguoid ripples have short, strongly curved open out upcurrent crestlines, as opposed to

40 barchanoids whose crestlines open out downcurrent (Allen 1968). 
(C) 2016. This manuscript version is made available under the CC-BY-NC-ND 4.0 license http://creativecommons.org/licenses/by-nc-nd/4.0/

Publisher version: doi: 10.1061/(ASCE)HY.1943-7900.0001212

41 Barchan ripples are bedforms related to sediment transport at below-capacity conditions (Mantz

42 1978), with geometry in plan of crescent moon (which explains the lunate terminology) and two

43 horns pointing towards the dominant flow direction. Subaqueous barchans have been reported in

44 fluvial (McCulloch and Janda 1964), marine (Hollister and McCave 1984) and estuarine (Allen

45 1968) environments, in laboratory experiments (Courrech du Pont et al. 2014; Endo et al. 2005;

46 Franklin and Charru 2011; Groh et al. 2009; Hersen 2005; Hersen et al. 2002; Katsuki et al. 2005;

47 Mantz 1978) and in industry (Boulanger and Wong 2016). Barchanoid-type bedforms comprise

48 not only isolated barchans but also parallel rows of coalesced barchans (McKee 1980), simply

49 called barchanoids, which may precede the barchan formation (Endo et al. 2005). The observations

50 from linear stability analysis on aeolian sand barchans are that barchan corridors are unstable

51 (although actual barchan corridors do not manifest such instabilities) (Hersen et al. 2004) and that

52 barchans can be formed from transverse dunes moving on a non-erodible bed (Melo et al. 2012;

53 Parteli et al. 2011).

54 Method

55 Experimental apparatus and sediment description

56 The experiments are performed in a rectangular tilting flume (Laboratory of Geological Processes

57 Simulation SIMGEO UB-CSIC, Universitat de Barcelona) $15 \mathrm{~m}$ long, $0.37 \mathrm{~m}$ wide and $0.40 \mathrm{~m}$

58 high. The floor consists of rigid polished aluminium and the walls are transparent glass. The water

59 and sediment mixture is constantly recirculated (Fig. 1) on the principle of mass conservation (i.e.

60 the sediment can only deposit on the bottom of the flume as the mixture is stirred in the rest of the

61 facility). Velocity is measured using the acoustic Doppler principle, water level is measured using

62 point gauges, and sediment concentration is obtained from oven-drying samples of mixture at 
(C) 2016. This manuscript version is made available under the CC-BY-NC-ND 4.0 license http://creativecommons.org/licenses/by-nc-nd/4.0/

Publisher version: doi: 10.1061/(ASCE)HY.1943-7900.0001212

63 different elevations. The temperature is also monitored. Direct town supply, drinking water is used

64 (salinity, $\mathrm{pH}$ and total hardness are $500 \mathrm{mg} / 1,7.5$ and $260 \mathrm{mg} \mathrm{CaCO}_{3}$, respectively).

65 The sediment is made of crushed rock and consists of $\mathrm{SiO}_{2}$ (quartz $>97 \%$ ) and traces of $\mathrm{Al}_{2} \mathrm{O}_{3}$,

$66 \mathrm{~K}_{2} \mathrm{O}, \mathrm{CaO}, \mathrm{Fe}_{2} \mathrm{O}_{3}$ and $\mathrm{TiO}_{2}$. The geometric mean size $D_{g}=4.15 \mu \mathrm{m}$ and the geometric standard

67 deviation $\sigma_{g}=2.38$ [Fig. 2(a)]. It is poorly sorted (Folk 1974) and noncohesive by definition

68 although beds made of this material may behave as cohesive (Roberts et al. 1998; te Slaa et al.

69 2015; Walder 2015). The settling velocity is obtained from Stokes' solution $w_{\mathrm{s}}=g \cdot R \cdot D^{2} /(18 \cdot v)$

70 valid for very small particles (Graf 1984), with $g=9.81 \mathrm{~m} / \mathrm{s}^{2}$ the acceleration of gravity, $R=1.6$

71 the submerged specific gravity of sediment (density of the silt $\rho_{s}=2600 \mathrm{~kg} / \mathrm{m}^{3}$ ), $v=0.77 \cdot 10^{-6} \mathrm{~m}^{2} / \mathrm{s}$

72 the mean water kinematic viscosity and $D$ a grain size. The settling velocities for the characteristic

73 grain sizes $D_{g}, D_{10}=1.25 \mu \mathrm{m}$ and $D_{90}=12.48 \mu \mathrm{m}$ are $1.95 \cdot 10^{-5} \mathrm{~m} / \mathrm{s}, 1.77 \cdot 10^{-6} \mathrm{~m} / \mathrm{s}$, and $1.76 \cdot 10^{-4}$

$74 \mathrm{~m} / \mathrm{s}$, respectively. The high resolution image in Fig. 2(b) shows particles with sharp edges and a

75 size range comprising from $<1 \mu \mathrm{m}$ to $\sim 10 \mu \mathrm{m}$.

76 Procedure

77 Quartz silt and $4.8 \mathrm{~m}^{3}$ of water are first mixed within the tank and then pumped (the aspect is that

78 of a dense milk). The stirring within the tank is never stopped. The initial conditions are always

79 the rigid, non-erodible clean floor of the flume but the initial sediment concentrations are varied

80 with a maximum of $51.72 \mathrm{~kg} / \mathrm{m}^{3}$ as described in Table 1 . The experiment starts after flow of water

81 and sediment is stabilized (Fig. 1) and runs continuously, with the hydraulic conditions constant

82 and without adding silt. At the end of the run the pump is turned off and the remaining water and

83 silt in suspension slowly evacuate the flume by gravity without modifying the bedforms. A trivial

84 quantity of silt may deposit during the emptying of the flume. 
(C) 2016. This manuscript version is made available under the CC-BY-NC-ND 4.0 license http://creativecommons.org/licenses/by-nc-nd/4.0/

Publisher version: doi: 10.1061/(ASCE)HY.1943-7900.0001212

85 Photographs of the new bed are taken and processed to obtain mean sizes of the bedforms (length and width). Bed thicknesses are measured with a point gauge and the laser diffraction technique is

87 used to obtain grain size distributions from samples of deposited silt.

88 The 12 experiments are classified in 3 groups based on their duration $t: 1)$ short experiments $(t=$

$89100 \mathrm{~min}) ; 2)$ one-day experiments $(t=1440 \mathrm{~min})$ and 3$)$ long experiments $(t \geq 2040 \mathrm{~min})$. The

90 bedform development and equilibrium hypotheses are tested by studying the different bed

91 morphologies at the end of the runs. The beds of silt constitute, on average, $10 \%, 33 \%$ and $41 \%$

92 of the initial silt in suspension in group 1, 2 and 3, respectively [Table 1].

93 The discharge is evaluated as $Q=U \cdot B \cdot h=7.7 \cdot 10^{-3} \mathrm{~m}^{3} / \mathrm{s}$, where $U=0.27 \mathrm{~m} / \mathrm{s}$ is the depth-averaged

94 velocity and $h=0.077 \mathrm{~m}$ is the flow depth. The flume bed slope is $S_{b}=6 \cdot 10^{-4}$ and the energy

95 gradient is $S_{f}=4.8 \cdot 10^{-4}$ from water level readings $10.7 \mathrm{~m}$ apart. The Reynolds number $\mathrm{Re}=$

$964 \cdot R_{h} \cdot U / v=7.5 \cdot 10^{4}$, where $R_{h}$ is the hydraulic radius, defines a turbulent flow, and the Froude

97 number $\mathrm{Fr}=U / \sqrt{ }(g \cdot h)=0.31$ defines a subcritical flow. The average shear velocity is approximated

98 as $u * \approx \sqrt{ }\left(g \cdot R_{h} \cdot S_{f}\right)=0.016 \mathrm{~m} / \mathrm{s}\left(\sim 90\right.$ times bigger than the settling velocity of a particle of size $\left.D_{90}\right)$.

99 The Chezy's resistance coefficient $C_{z}=U / u *$ is used to compute the equivalent bed roughness $k_{s}$

100 from the Colebrook and White relation (Henderson 1966), given as:

$$
\frac{C_{z}}{\sqrt{8}}=-2 \cdot \log _{10}\left(\frac{k_{s}}{12 \cdot R_{h}}+\frac{2.5 \cdot C_{z}}{\operatorname{Re} \cdot \sqrt{8}}\right)
$$

101 leading to $k_{s}=6.0 \cdot 10^{-4} \mathrm{~m}\left(\sim 50\right.$ times bigger than the quartz silt size $\left.D_{90}\right)$. The viscous sublayer is 102 defined as $\delta_{v}=11.6 \cdot v / u_{*}=5.6 \cdot 10^{-4} \mathrm{~m}$ so $0.25<k_{s} / \delta_{\mathrm{v}}<6.0$ and the bed is hydraulically in transition 103 (Cardoso 1998). 
(C) 2016. This manuscript version is made available under the CC-BY-NC-ND 4.0 license http://creativecommons.org/licenses/by-nc-nd/4.0/

Publisher version: doi: 10.1061/(ASCE)HY.1943-7900.0001212

$104 \quad \underline{\text { Results and discussion }}$

105 Regardless of the initial suspended sediment concentration, silt accumulations appear at the end of

106 our experiments as shown in Fig. 3 and Table 1. Mass deposition (Mehta 2013) is excluded based

107 on observations and the noncohesive character of the quartz silt. From E1 to E12 in Fig. 3, the

108 beds of quartz silt show an early stage of bed formation, evolve into barchans for the one-day

109 experiments and flatten into cohesive plane beds for the long experiments. Overall, the sequence

110 in Fig. 3 from group 1 ( $t=100 \mathrm{~min})$ to group $3(t \geq 2$ days) may reveal stages of the formation of

111 an equilibrium fine sediment bed from particle sedimentation. The deposition of silt occurs at a

112 faster rate during the first minutes (Fig. 4). The amount of deposited silt agrees with the decrease

113 of the suspended silt concentration. The measured wet and dry bulk density of the bed is 1820 and

$1141340 \mathrm{~kg} / \mathrm{m}^{3}$, respectively, which agrees with the values obtained in previous research with quartz

115 silt (Roberts et al. 1998; te Slaa et al. 2015). During the initial stage of the runs, with a faster

116 deposition rate, multiple small and coarse bedforms are created 8Fig. 3) but, over time, there are

117 changes in the bed morphology as a consequence of bedform migration and interactions and further

118 sedimentation of finer particles.

119 Group 1

120 The group 1 (E1 and E2 in Fig. 3) displays similar beds although initial silt concentration in E2

$121\left(21.30 \mathrm{~kg} / \mathrm{m}^{3}\right)$ is nearly three times the silt concentration in E1 $\left(7.51 \mathrm{~kg} / \mathrm{m}^{3}\right)$. The bed morphology

122 is defined as barchanoids because many of the bedforms appear in contact to each other. Following

123 Allen (1968), some 2D features are assigned to these bedforms because they are comparatively

124 much wider than higher $(W \sim 13 \cdot H$ as given in Table 1$)$; then, a crestline may be drawn to span

125 the whole width of the flume. Subsequently, bedforms are grouped in horizontal bands,

126 perpendicular to the main flow direction. It is termed barchan front [Fig. 5(a)]. 
(C) 2016. This manuscript version is made available under the CC-BY-NC-ND 4.0 license http://creativecommons.org/licenses/by-nc-nd/4.0/

Publisher version: doi: 10.1061/(ASCE)HY.1943-7900.0001212

127 Sidewall effects are clear in group 1, approximately up to a fifth of the total width from the

128 sidewall. Indeed, bedforms near the wall appear behind the rest of the bedforms of the barchan

129 front, a feature which may correspond to an initial state of the bedforms (Baas 1994).

130 In group 1 runs, $6.5 \mathrm{~cm}$ long barchanoids are $3 \mathrm{~cm}$ shorter approximately than the rest of the

131 experiments bedforms. The width and height, $4.8 \mathrm{~cm}$ and $0.5 \mathrm{~cm}$ respectively, are similar to the

132 rest of the experiment measures. The distance between two consecutive barchan fronts $\lambda$ is $\sim 9.1$

$133 \mathrm{~cm}$. A length $\lambda$ is also defined in E9 and E10.

134 Group 2

135 The initial silt concentration ranges between $1.3 \mathrm{~kg} / \mathrm{m}^{3}$ and $9.8 \mathrm{~kg} / \mathrm{m}^{3}$ and all experiments last one 136 day. In these quartz silt beds the barchans are discernible on the bottom of the flume. Specially E3

137 (Fig. 3) displays similarities with other research focused in the creation of barchans (e.g. Endo et

138 al. (2005)). The rear-point of the barchan is unclear when it resembles a comet [Fig. 5(b)] so, in

139 these cases, the length of the barchan $L$ does not include the tail. The cohesive-like behaviour of

140 the silt bed may explain the ripple elongation (Schieber et al. 2013).

141 A horn length $L_{h}$ is defined for all experiments with barchanoid morphology in spite of the

142 difficulty of interacting bedforms and the asymmetry. The average total length of the bedforms in

143 group 2 (i.e. the sum of the barchan length and the horn length) is $11.73 \mathrm{~cm}$. On average, bedforms

144 are $4.93 \mathrm{~cm}$ wide, $10.33 \mathrm{~cm}$ long and $0.45 \mathrm{~cm}$ high and have horns $1.40 \mathrm{~cm}$ long. The angle between

145 the lee-side and the floor of the flume is $20.1^{\circ}$ in average, smaller than the $\sim 30^{\circ}$ typically seen for 146 ripples (Allen 1968) and aeolian-dominated sandy material in desert barchans (Sauermann et al. 147 2000), although low-angle lee-side dunes $\left(<10^{\circ}\right)$ are also common (Best 2005). 
(C) 2016. This manuscript version is made available under the CC-BY-NC-ND 4.0 license http://creativecommons.org/licenses/by-nc-nd/4.0/

Publisher version: doi: 10.1061/(ASCE)HY.1943-7900.0001212

148 The barchans in group 2 have ratios $L_{h} / W$ and $L / W$ greater than 0.21 and 1.9 , respectively. The

149 former is slightly lower than 0.35 reported for barchans in unidirectional water flows (Endo et al.

150 2005).

151 The biggest bedforms appear for experiments with higher initial suspended silt [Table 1], with

152 barchans up to $0.69 \mathrm{~cm}$ high. Following Fig. 3, the average volume of a barchan grows [E3-E5],

153 shrinks [E6-E7] and ultimately grows [E8-E10], and the silt plane layer of thickness $s$ [Fig. 5(c)]

154 grows [E3-E8] and then shrinks [E9-E10]. This points to a competition between the barchan

155 formation and the deposition of particles as a plane layer.

156 The interactions between barchans are more noticeable for experiments with higher sediment

157 concentration. The processes of absorption, ejection and split taking place on the bottom of the

158 flume are suspected (Endo et al. 2004) and they may explain the decrease in the number of

159 bedforms from group 1 to group 2 observed in Table 1. The runs E9 and E10 have similar sediment

160 concentration and both have bigger bedforms than the rest on group 2. The bedforms in E9 and

161 E10 are touching each other, with merging horns, and they may resemble a barchan front. Between

162 consecutive barchans the floor of the flume may be visible.

163 The sidewall effects are not as clear on this group. Attached to the walls there are halved bedforms

164 in agreement with the moving bedforms that a viewer can see from the side of the flume, during

165 the experiments, and whose velocity can be measured as reported later.

166 Group 3

167 The beds of maximum thickness $s$ are obtained after experiments lasting 3 days (E11) and 2 days

168 (E12) with very high sediment concentration [Table 1]. Surprisingly, the morphology of these beds

169 is totally different from the rest of the experiments because the silt creates a plane layer, slightly

170 concave (the sides are thicker than the middle of the bed), that covers the whole length of the flume 
(C) 2016. This manuscript version is made available under the CC-BY-NC-ND 4.0 license http://creativecommons.org/licenses/by-nc-nd/4.0/

Publisher version: doi: 10.1061/(ASCE)HY.1943-7900.0001212

171 where bedforms have vanished. It is possible to spot few bedforms in the middle of the cross-

172 section, covering $1 / 3$ of the total width. The accumulation on the sides in E12 is up to $2.26 \mathrm{~cm}$

173 thick.

174 The plane beds in group 3 are presumably preceded by bedforms under the assumption that final 175 quartz silt beds formed in short experiments (e.g. E2) are also the quartz silt beds existing at an 176 intermediate time in long experiments (e.g. E11). As Andreotti et al. (2002) show that a flat bed is 177 unstable at large wavelengths from linear stability analysis, cohesion should play a role in the plane

178 bed observed in runs E11 and E12.

179 Migration rate and bed-load

180 The suspended quartz silt only allowed the visualization of migrating bedforms on the sidewall of 181 the flume, where they are altered by the presence of the wall (Fig. 3). The incipient bedforms (with 182 height less than $\sim 3 \mathrm{~mm}$ ) migrate at $\sim 4 \mathrm{~mm} / \mathrm{min}$, and over time they grow and migrate slower, at

$183 \sim 1 \mathrm{~mm} / \mathrm{min}$. As it is frequently reported, the migration rate and bedform height are inversely 184 proportional (Endo et al. 2004; Hersen 2005; Hersen et al. 2002; Simons et al. 1965). These 185 migration rates agree with the values from Hersen (2005) (using glass beads of $150 \mu \mathrm{m}$ ), but are 186 comparatively $\sim 80$ times smaller than the values from Endo et al. (2005) (using a mean particle 187 size of $100 \mu \mathrm{m})$. The reader should keep in mind that the quartz silt in the present experiments is 188 much smaller than the sediment size reported in the previous studies.

189 The velocity of the bedforms $V_{s} \approx 1 \mathrm{~mm} / \mathrm{min}$ is used to compute the observed bed-load transport 190 with the expression from Simons et al. (1965) for a regular sequence of triangular bedforms, 191 migrating without deforming, given as:

$$
Q_{b, o}=N \cdot \frac{H}{2} \cdot B \cdot(1-p) \cdot V_{s}
$$


(C) 2016. This manuscript version is made available under the CC-BY-NC-ND 4.0 license http://creativecommons.org/licenses/by-nc-nd/4.0/

Publisher version: doi: 10.1061/(ASCE)HY.1943-7900.0001212

192 where $Q_{b, o}$ is the observed bed-load transport in $\mathrm{m}^{3} / \mathrm{s}, H$ and $N$ are respectively the mean height of

193 the bedforms and the ratio of area of flume bottom with barchans to total area of flume bottom

194 given in Table $1, B=0.37 \mathrm{~m}$ is the flume width, and $p=0.48$ is the measured porosity of the bed

195 of silt. Then, the average observed bed-load is $Q_{b, o}=2.06 \cdot 10^{-9} \mathrm{~m}^{3} / \mathrm{s}$ (without considering the plane

196 layer of silt that sometimes covers the flume) and is some orders of magnitude smaller than the

197 suspended sediment transport (e.g. the suspended sediment transport is $3 \cdot 10^{-6} \mathrm{~m}^{3} / \mathrm{s}$ if the suspended

198 sediment concentration is $1 \mathrm{~kg} / \mathrm{m}^{3}$ ).

199 The bed-load is also evaluated with the transport equation from van Rijn (1984) — although it

200 should be used for sediment sizes $>200 \mu \mathrm{m}$ - given as:

$$
Q_{b, c}=0.053 \cdot B \cdot D \cdot \sqrt{g \cdot R \cdot D} \cdot \frac{T^{2.1}}{D_{*}^{0.3}}
$$

201 where $Q_{b, c}$ is the computed bed-load transport in $\mathrm{m}^{3} / \mathrm{s}, D$ is the bed particle size from Table $2, T=$

$202\left(u *^{2}-u *_{c}^{2}\right) / u_{*_{c}}^{2}$ with $u *_{c}$ the critical shear velocity for initiation of motion and $D *=D \cdot\left(R \cdot g / v^{2}\right)^{1 / 3}$.

203 The formula is computed for one particle size of $10 \mu \mathrm{m}$ and two values for the critical shear

204 velocity from van Rijn (2007): for noncohesive pure quartz grains $u *_{c}=0.006 \mathrm{~m} / \mathrm{s}$ and the bed-

205 load is $Q_{b, c}=1.94 \cdot 10^{-7} \mathrm{~m}^{3} / \mathrm{s}$; to account for cohesion effects on the bed $u *_{c}=0.013 \mathrm{~m} / \mathrm{s}$ and the

206 bed-load is $Q_{b, c}=1.14 \cdot 10^{-9} \mathrm{~m}^{3} / \mathrm{s}$. Therefore, although multiple simplifications have been

207 introduced, there is some agreement between the observed bed-load from only migrating bedforms

208 and the bed-load obtained from the transport equation of van Rijn (1984), provided the critical

209 shear velocity for initiation of motion is well defined.

210 Grain size

211 A reasonable assumption is that if a long experiment stops at the duration of the short experiment,

212 the two beds will be the same. On average, the bed is 2.3 times coarser than the silt in the initial 
(C) 2016. This manuscript version is made available under the CC-BY-NC-ND 4.0 license http://creativecommons.org/licenses/by-nc-nd/4.0/

Publisher version: doi: 10.1061/(ASCE)HY.1943-7900.0001212

213 suspended mixture in group 1 (short experiments) but is reduced to 1.6 times coarser in group 3

214 (long experiments) [Table 2]. Particularly, comparing the particle size distribution between beds

215 from groups 1, 2 and 3, there is an excess of the volume fraction of particles $\sim 13.6 \mu \mathrm{m}$ in group 1

216 whereas the beds from groups 2 and 3 contain an excess of particles of $\sim 5 \mu \mathrm{m}$.

217 The segregation of the particles during the bed formation relates to coarser fractions depositing

218 earlier, so the deposition rate is faster during an early stage of the run (Fig. 4). From the poorly

219 sorted silt in suspension $\left(\sigma_{g}=2.38\right)$, coarser particles may become trapped within the viscous

220 sublayer whereas finer particles are preferentially rejected as suggested by McCave (1970, 2008).

221 Formation of the bed

222 As the bed remains hydraulically in transition condition $\left(k_{s} / \delta_{v}<6\right)$ (Cardoso 1998), particles

223 entering the viscous sublayer may $a$ ) become trapped in the flume bed (McCave 2008); $b$ ) become

224 trapped in the stoss-layer of a barchan (Zhang et al. 2014); c) become resuspended by the vortices

225 originated in an upstream barchan (Endo et al. 2004); d) become resuspended because they are

226 ejected from the horns of the barchan (Zhang et al. 2014); or $e$ ) become entrained into suspension

227 by turbulent processes affecting the viscous sublayer (Niño et al. 2003). The aspects $c$ ) and $d$ ) do

228 not imply that particles escape the viscous sublayer and all these processes may unfold the

229 formation of fine sediment beds from a suspension.

230 As the threshold shear velocity of entrainment into suspension $u *_{s}$ (from Niño et al. (2003)

231 criterion) is greater than the estimated shear velocity for the experiments (e.g. if evaluated for a

232 particle size of $10 \mu \mathrm{m}, u_{s} / u * \approx 1.3$ ), particles captured within the viscous sublayer may not escape.

233 Therefore, viscous effects are twofold; first, they are probably responsible for the trapping of

234 particles on the bed; and second, they prevent bed erosion. 
(C) 2016. This manuscript version is made available under the CC-BY-NC-ND 4.0 license http://creativecommons.org/licenses/by-nc-nd/4.0/

Publisher version: doi: 10.1061/(ASCE)HY.1943-7900.0001212

235 From the previous ideas and the scrutiny of the beds in Fig. 3, particularly the sequence from E1

236 (group 1) to E3 (group 2), the bed formation is conjectured as: 1) particles are captured within the

237 viscous sublayer; 2) captured particles form barchan ripples, indicators of sediment transport under

238 below-capacity conditions (e.g. Mantz (1978)); 3) the supply of fine sediment to the viscous

239 sublayer does not cease; and 4) the interaction between barchans induces the reduction of the

240 number of barchans and its growth.

241 The transformation from group 2 bedform-covered floor to group 3 plane bed needs further

242 research. Not only the silt concentration is the maximum on group 3, but also the experiments are

243 the longest and the cohesive effects may be significant. It may involve the saturation of silt on the

244 bed and a change to at-capacity conditions of the silt transport, so the first barchans to appear on

245 the bed (e.g. E2 in group 1) cannot reshape the continuing deposition of particles. Also, viscous

246 effects and their presumed protective action on the bed may limit the supply of particles for full

247 bedform development (Baas et al. 2013). More detailed experimental analysis is required to test

248 these hypotheses.

249 Concluding remarks

250 Quartz silt in suspension deposits and develops multiple bed morphologies, contrary to the

251 anticipated complete suspension from the hydraulic conditions. Barchans appear on the bottom of

252 the flume, although the total supply of silt is abundant, presumably because the availability of 253 coarser particles capable of being deposited is limited. The bed flattens, probably as a result of the

254 cohesive effects on the deposited silt, and a plane bed is observed for experiments that last more

255 than two days with very high suspended sediment concentration. Van Rijn (1984) bed-load

256 transport formula approaches bed-load transport by bedform migration, provided the critical shear

257 velocity for initiation of motion is well defined. Ultimately, bed-load transport is several orders of 
(C) 2016. This manuscript version is made available under the CC-BY-NC-ND 4.0 license http://creativecommons.org/licenses/by-nc-nd/4.0/

Publisher version: doi: 10.1061/(ASCE)HY.1943-7900.0001212

258 magnitude smaller than suspended transport. The segregation of the particles during the bed

259 formation coarsens the bed, in contrast to silt remaining in suspension. Viscous effects are deemed

260 relevant during the process of bed formation. The reasons are twofold: acting as a trap for particles

261 and protecting the bed from erosion.

262 Acknowledgements

263 The authors thank the editors and the reviewers for their valuable comments. The authors note that

264 there are no data sharing issues.

$265 \underline{\text { References }}$

266 Allen, J. R. L. (1968). Current ripples: Their relation to patterns of water and sediment motion,

267 North-Holland, Amsterdam, Netherlands.

268 Andreotti, B., Claudin, P., and Douady, S. (2002). "Selection of dune shapes and velocities part 2:

269 A two-dimensional modelling." Eur. Phys. J. B, 28(3), 341-352.

270 Baas, J. H. (1994). “A flume study on the development and equilibrium morphology of current

271 ripples in very fine sand." Sedimentology, 41(2), 185-209.

272 Baas, J. H. (1999). “An empirical model for the development and equilibrium morphology of

273 current ripples in fine sand.” Sedimentology, 46(1), 123-138.

274 Baas, J. H., Best, J. L., and Peakall, J. (2011). "Depositional processes, bedform development and

275 hybrid bed formation in rapidly decelerated cohesive (mud-sand) sediment flows." Sedimentology,

276 58(7), 1953-1987.

277 Baas, J. H., Davies, A. G., and Malarkey, J. (2013). “Bedform development in mixed sand-mud:

278 The contrasting role of cohesive forces in flow and bed." Geomorphology, 182, 19-32. 
(C) 2016. This manuscript version is made available under the CC-BY-NC-ND 4.0 license http://creativecommons.org/licenses/by-nc-nd/4.0/

Publisher version: doi: 10.1061/(ASCE)HY.1943-7900.0001212

279 Bagnold, R. A. (1966). "An approach to the sediment transport problem from general physics.”

280 U.S. Geological Survey, Washington D. C.

281 Best, J. (2005). “The fluid dynamics of river dunes: A review and some future research directions.”

282 J. Geophys. Res., 110, F04S02.

283 Boulanger, J. A. R., and Wong, C. Y. (2016). "Sand suspension deposition in horizontal low-

284 concentration slurry pipe flows.” Granular Matter, 18(2), 15.

285 Cardoso, A. H. (1998). Hidráulica fluvial, Fundaçao Calouste Gulbenkian, Lisboa, Portugal.

286 Courrech du Pont, S., Narteau, C., and Gao, X. (2014). "Two modes for dune orientation."

287 Geology, 42(9), 743-746.

288 Endo, N., Sunamura, T., and Takimoto, H. (2005). "Barchan ripples under unidirectional water

289 flows in the laboratory: Formation and planar morphology." Earth Surf. Processes Landforms,

$29030(13), 1675-1682$.

291 Endo, N., Taniguchi, K., and Katsuki, A. (2004). "Observation of the whole process of interaction

292 between barchans by flume experiments." Geophys. Res. Lett., 31(12), L12503.

293 Folk, R. L. (1974). Petrology of sedimentary rocks, Hemphill Publishing, Austin TX.

294 Franklin, E. M., and Charru, F. (2011). "Subaqueous barchan dunes in turbulent shear flow. Part

295 1. Dune motion.” J. Fluid Mech., 675, 199-222.

296 Graf, W. H. (1984). Hydraulics of sediment transport, Water Resources, Highlands Ranch CO. 
(C) 2016. This manuscript version is made available under the CC-BY-NC-ND 4.0 license http://creativecommons.org/licenses/by-nc-nd/4.0/

Publisher version: doi: 10.1061/(ASCE)HY.1943-7900.0001212

297 Groh, C., Rehberg, I., and Kruelle, C. A. (2009). "How attractive is a barchan dune?" New J. Phys., 298 11(2), 023014.

299 Henderson, F. M. (1966). Open channel flow, Macmillan, New York.

300 Hersen, P. (2005). "Flow effects on the morphology and dynamics of aeolian and subaqueous

301 barchan dunes.” J. Geophys. Res., 110(F4), F04S07.

302 Hersen, P., Andersen, K. H., Elbelrhiti, H., Andreotti, B., Claudin, P., and Douady, S. (2004).

303 “Corridors of barchan dunes: Stability and size selection.” Phys. Rev. E, 69(1), 011304.

304 Hersen, P., Douady, S., and Andreotti, B. (2002). "Relevant length scale of barchan dunes.” Phys. 305 Rev. Lett., 89(26), 264301.

306 Hollister, C. D., and McCave, I. N. (1984). "Sedimentation under deep-sea storms." Nature, $307309(5965), 220-225$.

308 Jopling, A. V., and Forbes, D. L. (1979). "Flume study of silt transportation and deposition."

309 Geografiska Annaler. Series A, Phys. Geogr., 61(1/2), 67.

310 Katsuki, A., Kikuchi, M., and Endo, N. (2005). "Emergence of a barchan belt in a unidirectional

311 flow: Experiment and numerical simulation.” J. Phys. Soc. Jpn., 74(3), 878-881.

312 Mantz, P. A. (1978). "Bedforms produced by fine, cohesionless, granular and flakey sediments

313 under subcritical water flows." Sedimentology, 25(1), 83-103.

314 Mantz, P. A. (1992). "Cohesionless fine sediment bed forms in shallow flows.” J. Hydraul. Eng., 315 10.1061/(ASCE)0733-9429(1992)118:5(743), 743-764. 
(C) 2016. This manuscript version is made available under the CC-BY-NC-ND 4.0 license http://creativecommons.org/licenses/by-nc-nd/4.0/

Publisher version: doi: 10.1061/(ASCE)HY.1943-7900.0001212

316 McCave, I. N. (1970). "Deposition of fine-grained suspended sediment from tidal currents." $J$.

317 Geophys. Res., 75(21), 4151-4159.

318 McCave, I. N. (2008). "Size sorting during transport and deposition of fine sediments: Sortable

319 silt and flow speed." Contourites. Developments in Sedimentology, vol. 60, Elsevier, Amsterdam, $320 \quad 121-142$.

321 McCulloch, D. S., and Janda, R. J. (1964). “Subaqueous river channel barchan dunes.” J. Sediment.

322 Petrol., 34(3), 694-695.

323 McKee, E. (1980). “A study of global sand seas.” U.S. Geological Survey, Washington D. C.

324 Mehta, A. J. (2013). An introduction to hydraulics of fine sediment transport, World Scientific, 325 Hackensack NJ.

326 Melo, H. P. M., Parteli, E. J. R., Andrade, J. S., and Herrmann, H. J. (2012). "Linear stability

327 analysis of transverse dunes.” Phys. A: Stat. Mech. Appl., 391(20), 4606-4614.

328 Niño, Y., Lopez, F., and Garcia, M. (2003). "Threshold for particle entrainment into suspension.”

329 Sedimentology, 50(2), 247-263.

330 Parteli, E. J. R., Andrade, J. S., and Herrmann, H. J. (2011). "Transverse instability of dunes."

331 Phys.Rev. Lett., 107(18), 1-5.

332 Raudkivi, A. J. (1997). "Ripples on stream bed.” J. Hydraul. Eng., 10.1061/(ASCE)0733-

333 9429(1997)123:1(58), 58-64.

334 Roberts, J., Jepsen, R., Gotthard, D., and Lick, W. (1998). "Effects of particle size and bulk density 
(C) 2016. This manuscript version is made available under the CC-BY-NC-ND 4.0 license http://creativecommons.org/licenses/by-nc-nd/4.0/

Publisher version: doi: 10.1061/(ASCE)HY.1943-7900.0001212

335 on erosion of quartz particles." J. Hydraul. Eng., 10.1061/(ASCE)0733-9429(1998)124:12(1261),

336 1261-1267.

337 Sauermann, G., Rognon, P., Poliakov, A., and Herrmann, H. (2000). "The shape of the barchan

338 dunes of Southern Morocco.” Geomorphology, 36(1-2), 47-62.

339 Schieber, J., Southard, J. B., Kissling, P., Rossman, B., and Ginsburg, R. (2013). “Experimental

340 deposition of carbonate mud from moving suspensions: Importance of flocculation and

341 implications for modern and ancient carbonate mud deposition.” J. Sediment. Res., 83(11), 1025-

3421031.

343 Simons, D. B., Richardson, E. V., and Nordin, C. F. (1965). "Bedload equation for ripples and

344 dunes." U.S. Geological Survey, Washington D. C.

345 Southard, J. B., and Boguchwal, L. A. (1990). "Bed configuration in steady unidirectional water

346 flows - Part 2: Synthesis of flume data.” J. Sediment. Res., 60(5), 658-679.

347 te Slaa, S., van Maren, D. S., He, Q., and Winterwerp, J. C. (2015). "Hindered settling of silt.” J.

348 Hydraul. Eng., 10.1061/(ASCE)HY.1943-7900.0001038, 04015020.

349 van Rijn, L. C. (1984). "Sediment transport-Part I: Bed load transport." J. Hydraul. Eng., 350 10.1061/(ASCE)0733-9429(1984)110:10(1431), 1431-1456.

351 van Rijn, L. C. (2007). “Unified view of sediment transport by currents 472 and waves. I: Initiation

352 of motion, bed roughness, and bed-load transport." J. Hydraul. Eng., 10.1061/(ASCE)0733-

353 9429(2007)133:6(649), 649-667. 
(C) 2016. This manuscript version is made available under the CC-BY-NC-ND 4.0 license http://creativecommons.org/licenses/by-nc-nd/4.0/

Publisher version: doi: 10.1061/(ASCE)HY.1943-7900.0001212

(c) commons

354 Walder, J. (2015). "Dimensionless Erosion Laws for Cohesive Sediment." J. Hydraul. Eng., 355 10.1061/(ASCE)HY.1943-7900.0001068, 04015047.

356 Zhang, D., Yang, X., Rozier, O., and Narteau, C. (2014). "Mean sediment residence time in

357 barchan dunes.” J. Geophys. Res. Earth Surf., 119(3), 451-463. 
(C) 2016. This manuscript version is made available under the CC-BY-NC-ND 4.0 license http://creativecommons.org/licenses/by-nc-nd/4.0/

Publisher version: doi: 10.1061/(ASCE)HY.1943-7900.0001212

359 Table 1. Silt concentration and silt bed morphology

\begin{tabular}{|c|c|c|c|c|c|c|c|c|c|c|c|c|c|}
\hline Code & $\begin{array}{l}t \\
(\min )\end{array}$ & $\begin{array}{l}C_{0} \\
\left(\mathrm{~kg} / \mathrm{m}^{3}\right)\end{array}$ & $\begin{array}{l}C_{f} \\
\left(\mathrm{~kg} / \mathrm{m}^{3}\right)\end{array}$ & )$^{n}$ & $N$ & $\begin{array}{l}W \\
(\mathrm{~cm})\end{array}$ & $\begin{array}{l}L \\
(\mathrm{~cm})\end{array}$ & $\begin{array}{l}H \\
(\mathrm{~cm})\end{array}$ & $\begin{array}{l}H_{\max } \\
(\mathrm{cm})\end{array}$ & $\begin{array}{l}L_{h} \\
(\mathrm{~cm})\end{array}$ & $\begin{array}{l}\lambda \\
(\mathrm{cm})\end{array}$ & $\begin{array}{l}\text { vol. } \\
\left(\mathrm{cm}^{3}\right)\end{array}$ & $\begin{array}{l}s \\
(\mathrm{~cm})\end{array}$ \\
\hline & \multicolumn{13}{|c|}{ Group 1} \\
\hline E1 & 100 & 7.51 & 6.81 & 900 & 0.36 & 4.48 & 6.13 & 0.35 & 0.51 & - & 8.98 & 3.20 & 0.00 \\
\hline E2 & 100 & 21.30 & 19.22 & 900 & 0.40 & 4.84 & 6.31 & 0.38 & 0.50 & - & 9.14 & 3.87 & 0.05 \\
\hline \multicolumn{14}{|c|}{ Group 2} \\
\hline E3 & 1440 & 1.28 & 0.87 & 200 & 0.11 & 4.24 & 9.00 & 0.37 & 0.53 & 1.47 & - & 4.89 & 0.00 \\
\hline E4 & 1440 & 1.99 & 1.30 & 250 & 0.19 & 4.87 & 10.40 & 0.39 & 0.53 & 1.54 & - & 6.82 & 0.00 \\
\hline E5 & 1440 & 3.01 & 2.00 & 250 & 0.22 & 5.24 & 11.29 & 0.37 & 0.62 & 1.53 & - & 7.53 & 0.02 \\
\hline E6 & 1440 & 3.57 & 2.18 & 250 & 0.18 & 4.79 & 10.14 & 0.41 & 0.62 & 1.29 & - & 6.84 & 0.05 \\
\hline E7 & 1440 & 4.44 & 2.96 & 220 & 0.13 & 4.19 & 8.98 & 0.33 & 0.56 & 1.25 & - & 4.28 & 0.08 \\
\hline E8 & 1440 & 4.52 & 3.02 & 220 & 0.12 & 4.37 & 9.48 & 0.34 & 0.56 & 1.26 & - & 4.84 & 0.08 \\
\hline E9 & 1440 & 9.17 & 6.42 & 450 & 0.43 & 5.59 & 11.73 & 0.67 & 0.79 & 1.55 & 17.35 & 15.10 & 0.04 \\
\hline E10 & 1440 & 9.82 & 7.09 & 500 & 0.52 & 6.11 & 11.65 & 0.69 & 0.83 & 1.31 & 15.94 & 16.81 & 0.00 \\
\hline \multicolumn{14}{|c|}{ Group 3} \\
\hline E11 & 4320 & 22.46 & 11.95 & - & - & - & - & - & 1.17 & - & - & - & 0.70 \\
\hline E12 & 2040 & 51.72 & 33.04 & - & - & - & - & - & 2.26 & - & - & - & 1.25 \\
\hline
\end{tabular}

360 Note: $C_{0}=$ initial and $C_{f}=$ final suspended sediment concentration. Measurements relate to a single

361 bedform of average dimensions; $n=$ approximate total number of bedforms on the entire floor of

362 the flume; $N=$ ratio of area of flume bottom with barchans to total area of flume bottom where the

363 area of one barchan is evaluated as the area enclosed by an ellipse (stoss-side) and a parabola

364 (toeline); $W=$ width between horns, $L=$ body length, $H=$ height, $L_{h}=$ horn length $H_{\max }=$

365 maximum bedform height in $\mathrm{cm} ; \lambda=$ distance between consecutive barchans fronts; vol. = volume

366 of a barchan $\left(\mathrm{cm}^{3}\right)$, evaluated by slicing the barchan in triangles defined by an ellipse and a

367 parabola (they define the base of the triangle) and the height, which is related to the base through

368 invariant lee-side and the stoss-side angles; $s=$ thickness $(\mathrm{cm})$ of a plane layer that covers the

369 whole flume bed on top of which the ripples are an addition [Fig. 5(c)]. Average standard 
(C) 2016. This manuscript version is made available under the CC-BY-NC-ND 4.0 license http://creativecommons.org/licenses/by-nc-nd/4.0/

Publisher version: doi: 10.1061/(ASCE)HY.1943-7900.0001212

\section{(c) commons}

370 deviations of the measures of width, length, height and horn length are $1.14 \mathrm{~cm}, 2.17 \mathrm{~cm}, 0.13 \mathrm{~cm}$

371 and $0.53 \mathrm{~cm}$, respectively.

372

373 Table 2. Silt bed grain size

\begin{tabular}{|l|c|c|c|c|}
\hline Silt bed & Initial & Group 1 & Group 2 & Group 3 \\
\hline$D_{10}(\mu \mathrm{m})$ & 1.25 & 2.49 & 1.96 & 1.80 \\
\hline$D_{50}(\mu \mathrm{m})$ & 4.37 & 11.17 & 9.78 & 21.14 \\
\hline$D_{90}(\mu \mathrm{m})$ & 12.48 & 25.33 & 23.24 & 7.95 \\
\hline$D_{g}(\mu \mathrm{m})$ & 4.15 & 9.35 & 7.97 & 6.78 \\
\hline$\sigma_{g}(-)$ & 2.38 & 2.48 & 2.78 & 2.73 \\
\hline
\end{tabular}

374 Note: $D_{x}=$ size for which $x \%$ of the sample is finer. Initial grain size relates to sediment in 375 suspension at the beginning of the experiments.

376

$377 \quad$ List of Figures

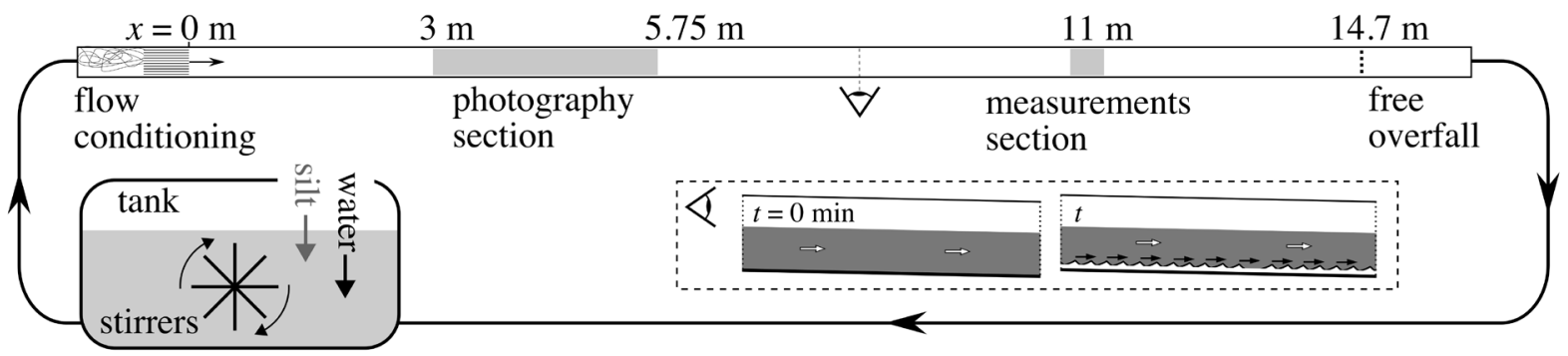

379 Fig. 1. Schematic drawings of the experiments.
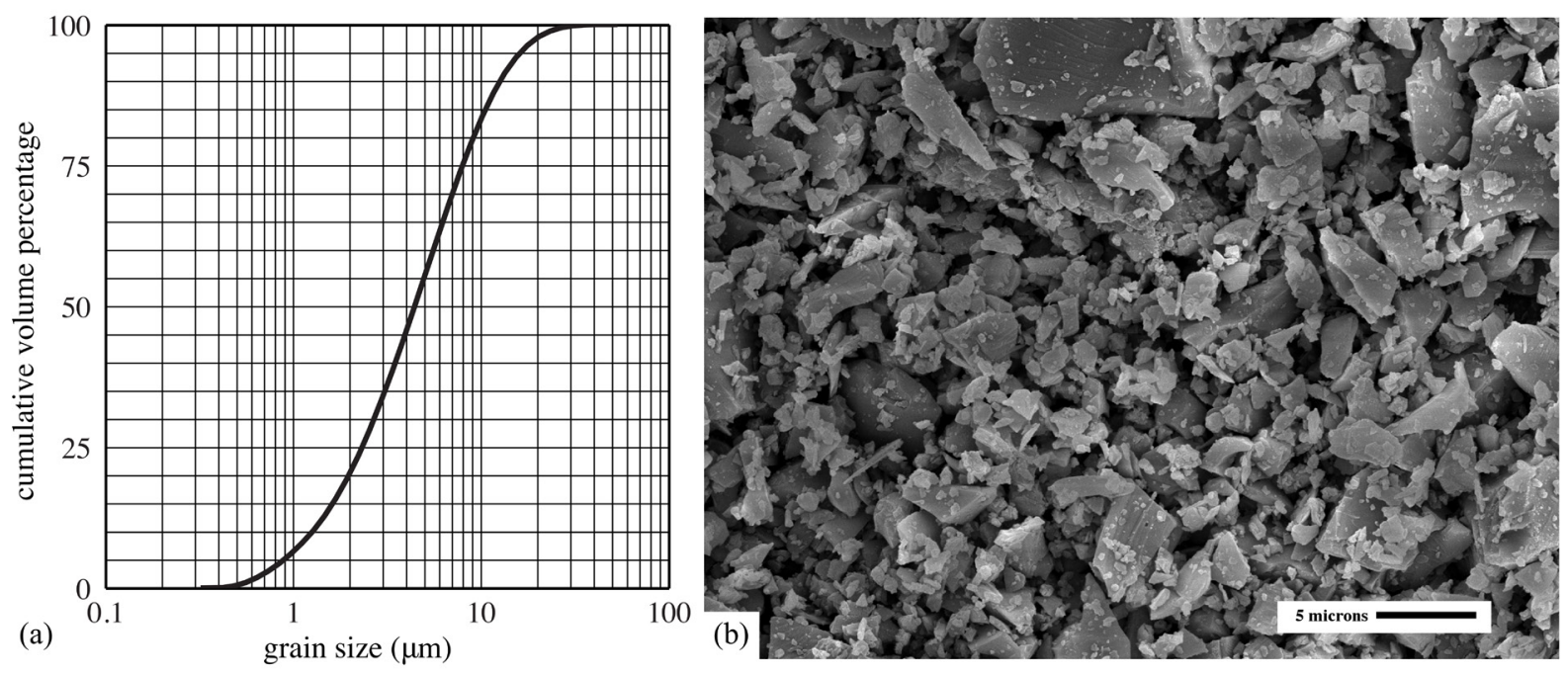
(C) 2016. This manuscript version is made available under the CC-BY-NC-ND 4.0 license http://creativecommons.org/licenses/by-nc-nd/4.0/

Publisher version: doi: 10.1061/(ASCE)HY.1943-7900.0001212 œcreative

381 Fig. 2. (a) Cumulative size distribution of the quartz silt; (b) high-resolution image of the particles.

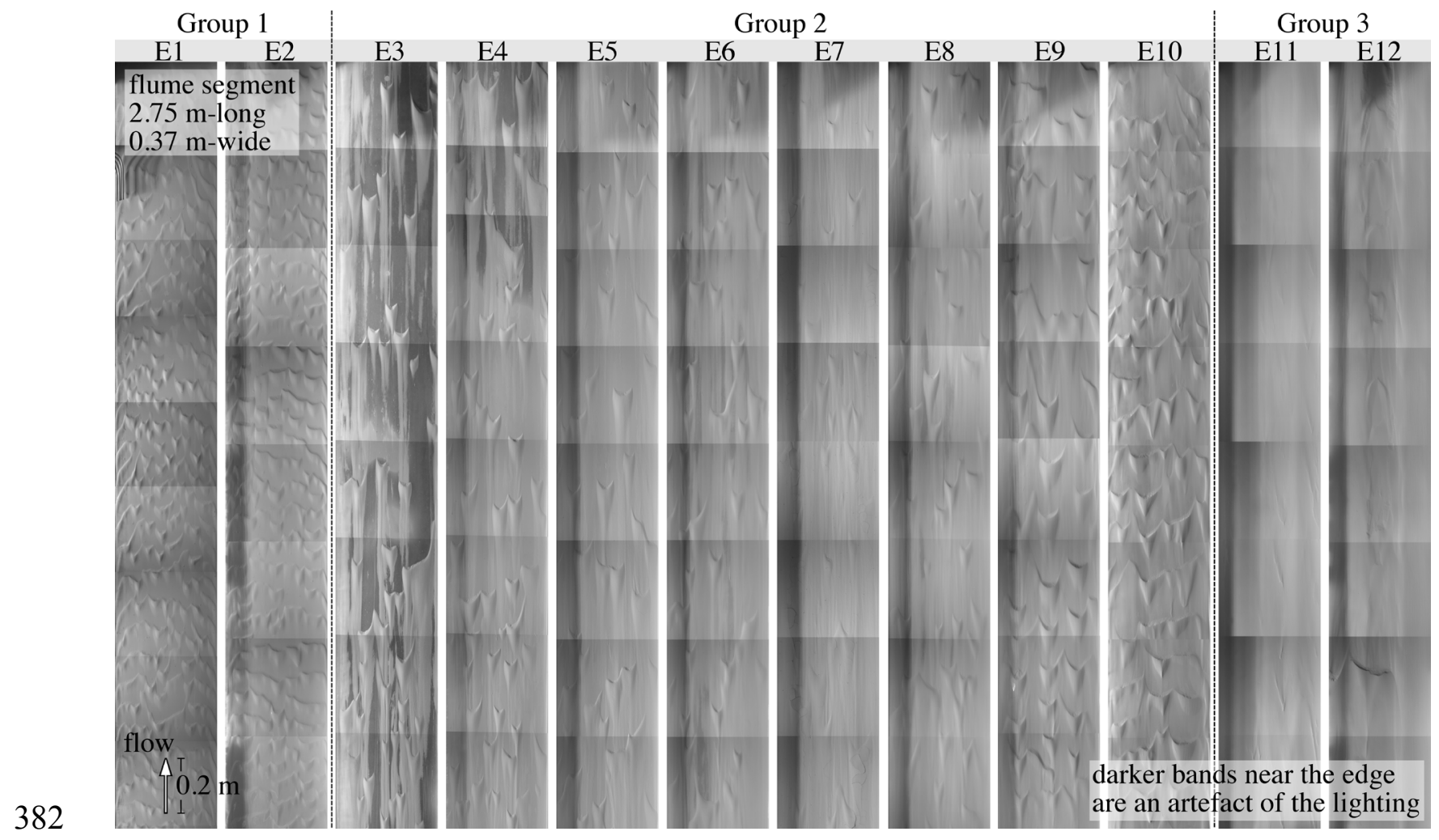

383 Fig. 3. Beds of quartz silt at the end of the experiments. 
(C) 2016. This manuscript version is made available under the CC-BY-NC-ND 4.0 license http://creativecommons.org/licenses/by-nc-nd/4.0/

Publisher version: doi: 10.1061/(ASCE)HY.1943-7900.0001212

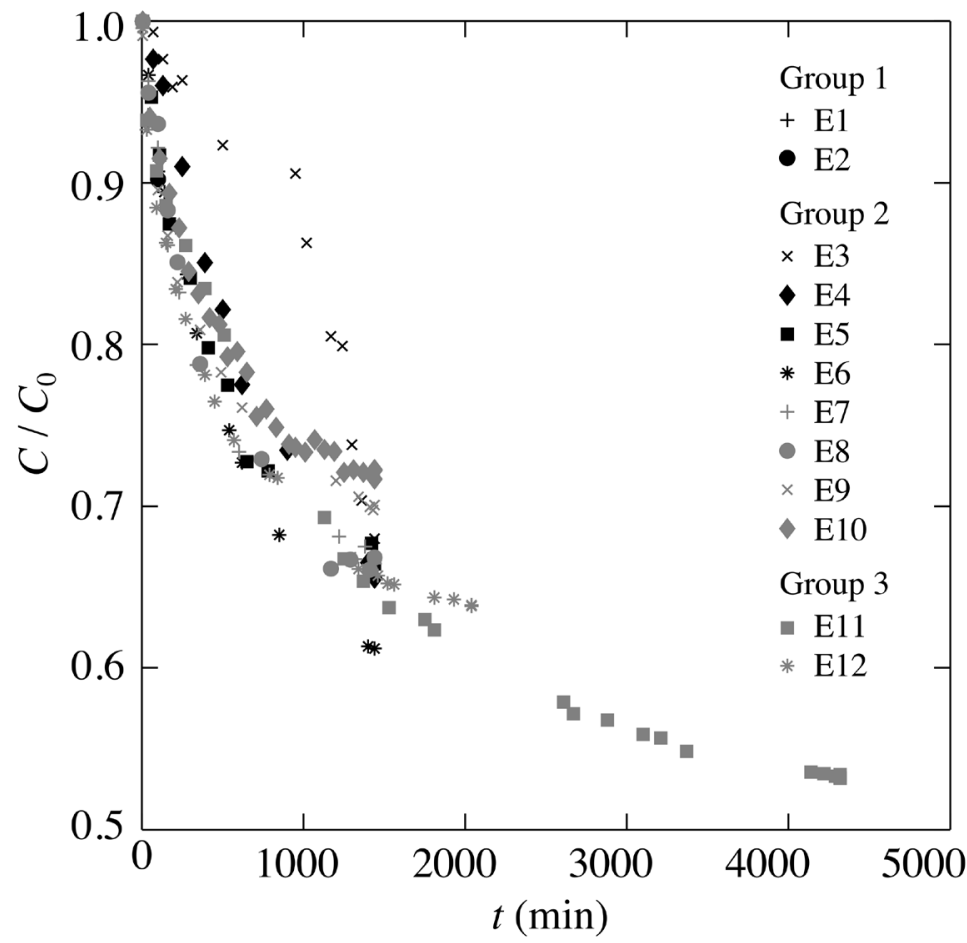

385 Fig. 4. Decrease in relative concentration over time.

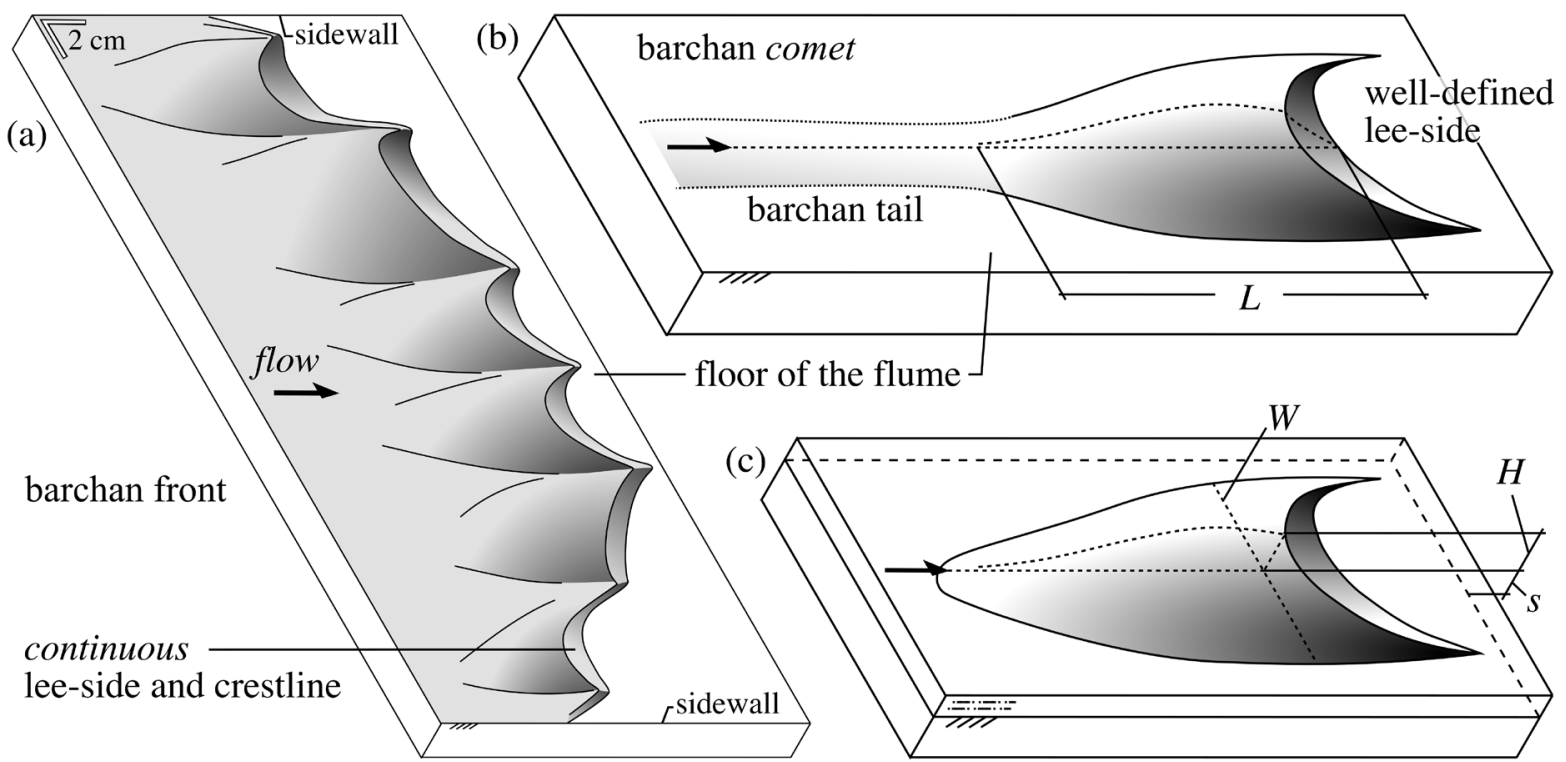

387 Fig. 5. Quartz silt bed elements: (a) barchan front; (b) barchan comet; (c) barchan emerging from a silt layer 